\title{
Rainfall Variability and Trends over Central Ethiopia
}

\author{
Wagaye Bahiru Abegaz ${ }^{1 *}$ and Antensay Mekoya ${ }^{2}$ \\ ${ }^{1}$ National Meteorology Agency of Ethiopia, East Amhara Meteorological Service Center, Ethiopia \\ ${ }^{2}$ Ethiopia Environment and Forest Research Institute, Bahir Dar Environment and Forest Research Center, Ethiopia
}

Submission: April 30, 2020; Published: May 18, 2020

*Corresponding author: Wagaye Bahiru Abegaz, National Meteorology Agency of Ethiopia, East Amhara Meteorological Service Center, P.O. Box: 94 Kombolcha, Ethiopia

\section{Abstract}

The rainfall variability and trends over North Shewa investigated using gauge as well as gridded rainfall data from 1985 to 2018. The variability of rainfall in both annual and seasonal scales were evaluated using coefficient of variation (CV), standardized rainfall anomaly, precipitation concentration index (PCI), and standardized precipitation index. Mann-Kendall test and Sen's slope estimator were used to assess the rainfall trends. The rainfall in North Shewa was found to be highly variable both in space and time; i.e., irregular rainfall distribution was observed $(\mathrm{PCI}=20 \%)$. The coefficient of variation showed moderate variation in both annual and Kiremt (June-September) rainfall as compared to the rainfall in Belg (February-May) and Bega (October-January) seasons. Mann-Kendall test resulted a decreasing trend in Belg and Bega seasons and an increasing trend for annual and Kiremt rainfall. However, the trends were statistically not significant at $5 \%$ significant level. The onset and cessation dates showed a non-significant decreasing and increasing trends, respectively. Whereas, the length of growing period showed a significant increasing trend. Overall, in North Shewa, the wet season (Kirmet) has been wetter while the dry and small rainy seasons (Bega and Belg) have been drier; North Shewa has been vulnerable to drought during Belg season (CV > 30\%). Due to the high contribution of Kiremt season for annual rainfall amount of about $75 \%$, the annual rainfall has also showed an increasing trend.

Keywords: Rainfall onset \& ending; Anomaly; Dry spell; LGP; SPI; Gauge \& gridded data; North Shewa

Abbreviations: CT: Contribution of Seasonal Rainfall to Annual Rainfall; PCI: Precipitation Concentration Index; SRA: Standardized Rainfall Anomaly; LGP: Length of Growing Period; SPI: Standardized Precipitation Index; Kiremt: 'Main' Rainy Season (June-September); Bega: 'Dry' Season (October-January); Belg: 'Small’ Rainy Season (February-May)

\section{Introduction}

Rainfall is one of the most important climate elements for agricultural production throughout the world [1]. It is also the most important climate element for rainfed agriculture and the general socio-economic development of Ethiopia [2]. Rainfall variability affects water resources sustainability which includes the availability, management, and utilization of water resources. This, in turn, may affect ecosystems, land productivity, agriculture, food security, water quantity and human health [3]. When the uneven distribution of rainfall results in a mismatch between water availability and demand, irrigation structures are required to redistribute water concerning the requirements of a specific region [4]. Hence, for ecosystem resilience and sustainable agricultural activities, accurate estimation of the spatial and temporal distribution of rainfall is crucial, particularly for rain-fed agriculture [5,6].
Various trend analysis of rainfall at different spatial (e.g., regional and national) and temporal (e.g., annual, seasonal, and monthly) scales have been studied which indicated changes in the spatial and temporal variability and trends. For example, according to Gamachu [7] rainfall in Ethiopia has shown large variations across time and space, due to the complex topography and varying latitude of the country [7]. Spatially, the amount, seasonal cycle, onset and cessation times of rainfall as well as the length of growing period, have shown variability across the country $[7,8]$. Temporally, it varies from days to decades, with the magnitude and direction of historic rainfall trends varying from region to region and season to season [9-12]. This complex Spatiotemporal variability of rainfall over Ethiopia is attributed to the large variations in altitude, variations in sea surface temperatures (SSTs) over the Indian, Pacific and Atlantic Oceans and the inter- 
seasonal and interannual variation of the strength of the monsoon over the Arabian Peninsula [7,8,13-15].

Although various studies indicated changes in the variability and trends of rainfall over Ethiopia, they are not consistent and clear. Because the climate of Ethiopia is geographically quite diverse, due to its equatorial positioning and varied topography (Enyew \& Steeneveld, 2014). Also, the national (even the regional) rainfall variability studies mask zonal scale variabilities as Ethiopia is a large country in size; more than three times bigger than Germany. Therefore, investigation of rainfall variability and trends at a local level (at a smaller area with higher resolution) has enormous advantage for a country like Ethiopia where the economy is mainly dependent on rain fed agriculture; it helps the decision-makers to take appropriate measures. In view of that, Fitsum et al. [16] are probably the first to analyze rainfall variability and trends at Bale zone (southeastern part of Ethiopia).

In contrast to the study by Fitsum et al. [16], in this study, the spatial variability and the temporal trend of rainfall using gauge as well as gridded rainfall data are investigated in a more detailed way for North Shewa (central part of Ethiopia). Consideration of the analysis of both the spatial variability and the temporal trend of the number of rainy days, onset, ending, and length of growing period (LGP) for the main rainy season (Kiremt) makes this study unique. On top of that, consideration of the precipitation concentration index as well as consideration of the analysis meteorological drought indices such as the probability of dry spell occurrence, standardized rainfall anomaly, and standardized precipitation index for Belg and Kiremt seasons makes this study unique. Note also that the study sites are located in different climate regions [17]. For example, North Shewa received the highest rainfall amount during Kiremt season $(75 \%$ of the annual rainfall); whereas, Bale zone received it during Belg season ( $42.5 \%$ of the annual rainfall); Bale zone received only $33.3 \%$ of the annual rainfall during Kiremt season [16,17].

As a final point, using gauge rainfall data is more reliable than satellite data because satellite rainfall values are just estimates which have various sources of uncertainty [18]. Also, the gaugebased data sets have generally provided long-term records of precipitation, which are suitable for climate studies whereas the satellite-related data sets have the limitations of their short length of record [19].

\section{Data and Methodology}

\section{Description of the study area}

The study was conducted in North Shewa which is one of the 11 administrative zones of Amhara National Regional State, Ethiopia (see Table 1 and Figure 1). It is located in between 9o $11^{\circ} \mathrm{N}$ latitude, and $38^{\circ}-40 \cong \mathrm{E}$ longitudes with an area of about $15,936 \mathrm{~km}^{2}$. According to the Central Statistical Agency of Ethiopia (2007), North Shewa had a total population of 1,837,490; 928,694 men and 908,796 women.

Table 1: Location of the meteorological stations and length of rainfall series.

\begin{tabular}{|c|c|c|c|c|}
\hline Stations & Latitude (North) & Longitude (East) & Altitude (in m) & Years of Observation \\
\hline Alemketema & $10.03^{\circ}$ & $39.71^{\circ}$ & 2204 & $1985-2018$ \\
\hline Alyuamba & $9.56^{\circ}$ & $39.78^{\circ}$ & 1813 & $1985-2018$ \\
\hline Debrebirhan & $9.7^{\circ}$ & $39.5^{\circ}$ & 3206 & $1985-2018$ \\
\hline Effeson & $10.34^{\circ}$ & $39.87^{\circ}$ & 1447 & $1985-2017$ \\
\hline Enewari & $9.8^{\circ}$ & $39.2^{\circ}$ & 2667 & $1985-2018$ \\
\hline Ginager & $9.34^{\circ}$ & $39.58^{\circ}$ & 3112 & $1985-2017$ \\
\hline Gisherabel & $10.54^{\circ}$ & $39.6^{\circ}$ & 3075 & $1985-2018$ \\
\hline Gudoberet & $9.8^{\circ}$ & $39.68^{\circ}$ & 2504 & $1985-2017$ \\
\hline Gundomeskel & $10.2^{\circ}$ & $38.9^{\circ}$ & $305-2018$ \\
\hline Majete & $10.5^{\circ}$ & $39.85^{\circ}$ & 3084 & $1985-2018$ \\
\hline Mehalmeda & $10.3^{\circ}$ & $39.7^{\circ}$ & 2572 & $1985-2018$ \\
\hline Meragna & $10.2^{\circ}$ & $39.09^{\circ}$ & 3046 & $1985-2017$ \\
\hline Molale & $10.12^{\circ}$ & $39.66^{\circ}$ & 2054 & $1985-2016$ \\
\hline Rema & $10.34^{\circ}$ & $39.58^{\circ}$ & 1277 & $1985-2017$ \\
\hline Shewarobit & $10^{\circ}$ & $39.9^{\circ}$ & 2839 & $1985-2017$ \\
\hline Sholagebeya & $9.2^{\circ}$ & $39.6^{\circ}$ & 3257 & $1985-2018$ \\
\hline Yigem & $10.23^{\circ}$ & $39.77^{\circ}$ & 2850 & $1985-2018$ \\
\hline Zemero & $10.23^{\circ}$ & $39.43^{\circ}$ & $1985-2018$ \\
\hline
\end{tabular}




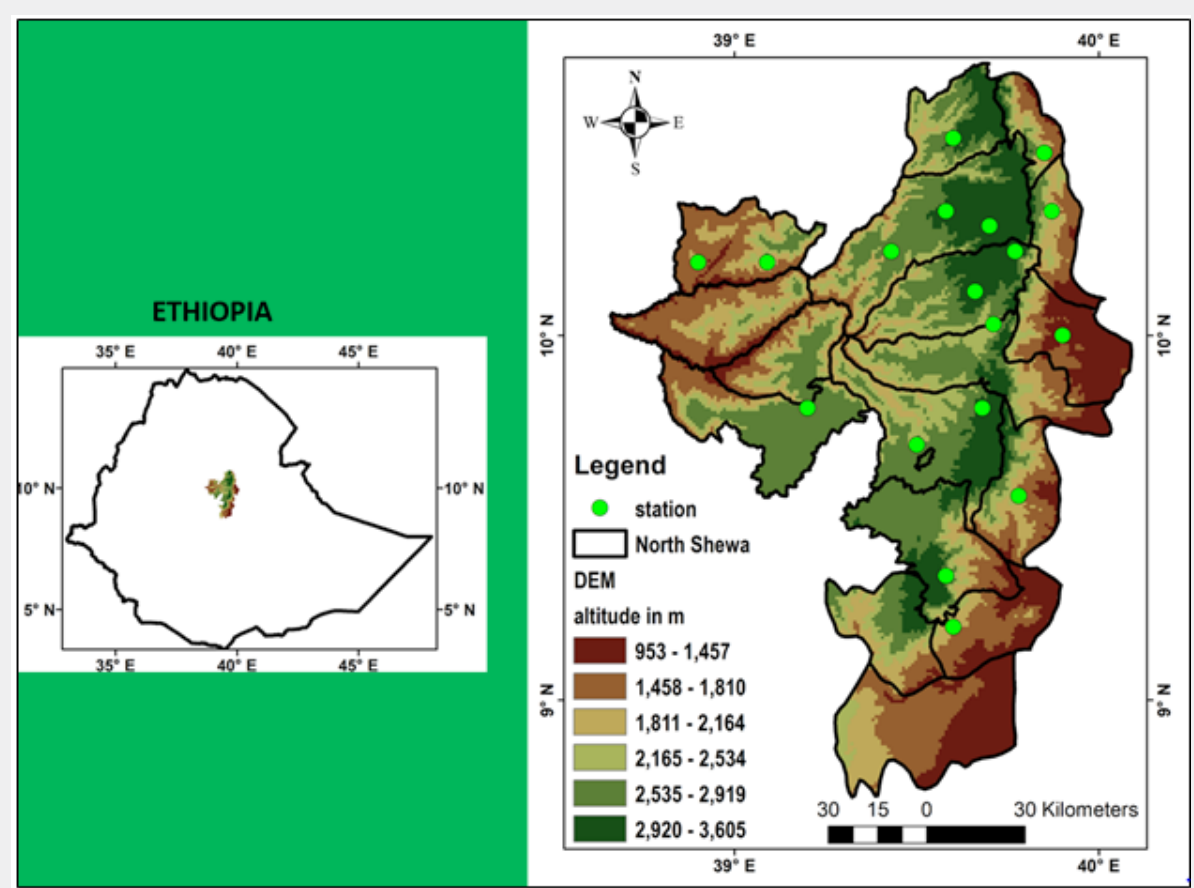

Figure 1: Map of North Shewa zone (study area).

The topography comprises uneven and rugged mountainous highlands in the northern and central parts of the zone, extensive plains and also deep gorges and cliffs in the periphery [20]. The topographic feature of the administration is lower in the south, west and east peripheries and higher in the central part of the zone [21]. The zone has four agro-ecological zones; namely, lowland: 500-1500m a.s.l, mid-latitude: $1500-2300 \mathrm{~m}$ a.s.l, highland: 2300 $3200 \mathrm{~m}$ a.s.l, and 'Wurch': above 3200m a.s.l.

North Shewa is characterized by three distinct seasons with four months each, classified based on the climatology of rainfall and temperature. These seasons are locally known as 'Bega' (ONDJ), 'Belg' (FMAM), and 'Kiremt' (JJAS) (Mekonnen et al. 2018). Kiremt and Belg are the main and small rain seasons, respectively while Bega is the dry season of the zone. The rain seasons have been inconsistent with respect to the onset, ending, distribution, and amount of rainfall due to the seasonal movement of the ITCZ to north in July and south in January, the atmospheric circulation associated with ITCZ, and the complex topography with a marked contrast in elevation. As a result of climate change, currently, the rain seasons (Kiremt and Belg) are becoming more inconsistent [22].

According to current studies, on average North Shewa receives a mean annual rainfall ranging between $790.3-1765.1 \mathrm{~mm}$. At the seasonal scale, it receives 633.2-1071.2, 121.1-483.5, and 25.3209.1 millimeters in Kiremt, Belg and Bega seasons, respectively.

\section{Data sources and data quality control}

\section{Source of data}

Very good quality of gauge or station as well as gridded daily rainfall data was obtained from the National Meteorological Agency of Ethiopia (NMA) from 1985 to 2018 for the selected 18 meteorological stations.

\section{Data quality control assessment}

Detected outliers were removed using the Turkey fence approach [23]. The data series was also examined for homogeneity and no heterogeneity was detected. Missing data in the time series was filled with data from neighboring stations using statistical regression techniques as described in [24] and applied in various studies $[9,25]$. Additionally, the missing data were filled with gridded data. The gridded data are constructed data series based on records of gauge stations and satellite observations. This data is very useful because weather stations are limited in number and unevenly distributed and have sometimes a short period of observations.

\section{Methodology}

In this study, we employed INSTAT, Genstat, XLSTAT, R (RStudio), and MS Excel spreadsheet tools to analyses our data set. Graphs were mapped using ArcGIS software; inverse distance weighting was used for spatial interpolation $[26,27]$.

\section{Analysis of rainfall variability}

Variability of rainfall has been computed using coefficient of variation (CV) (see Hare 1983), standardized rainfall anomaly (SRA) (see Agnew \& Chappel 1999), precipitation concentration index (PCI) [28], and standardized precipitation index (SPI) [29]. Contribution of seasonal rainfall to the total annual rainfall in percent (CT) for each station is also computed. 
For analysis, the monthly rainfall of all the stations was used to calculate an areal average rainfall for North Shewa using the equation of Nicholson [30], i.e., $R_{j}=\frac{\sum_{i=1} X_{i j}}{I}[30]$; where $\mathrm{R}_{\mathrm{j}}$ is a real integrated rainfall for year $\mathrm{j} ; \mathrm{X}_{\mathrm{ij}}$ is rainfáll at station i for year $\mathrm{j}$ and $\mathrm{I}_{\mathrm{j}}$ is the number of stations available for year $\mathrm{j}$.

\section{Analysis of rainfall trend}

To estimate the sign and slope of long-term rainfall trends for the selected study sites, Mann-Kendall's trend test [31,32] and
Sen's slope estimation method [33] were used.

The presence of a statistically significant trend is evaluated using the ZMK value [31,32]. In a two-sided trend test, the null hypothesis $H_{0}$ should be accepted if $\left|Z_{M K}\right|<Z 1-\alpha / 2$ at a given level of significance. Z1- $\alpha / 2$ is the critical value of ZMK from the standard normal table. E.g. for $5 \%$ significant level, the value of $\mathrm{Z} 1-\alpha / 2$ is 1.96 . In this study, a $5 \%$ significant level is used. Note also that the modified Mann-Kendall test [34] was not applied as the data has no serial dependence.

\section{Results and Discussion}

\section{Temporal and spatial rainfall distribution}

\section{Annual and seasonal rainfall variability}

Table 2: Mean annual and seasonal rainfall $(\mathrm{mm})$, coefficient of variation (CV \%), the contribution of seasonal rainfall to the annual rainfall (CT \%) and precipitation concentration index (PCI \%) for 18 meteorological stations.

\begin{tabular}{|c|c|c|c|c|c|c|c|c|c|c|c|c|}
\hline \multirow{2}{*}{ Stations } & \multicolumn{3}{|c|}{ Kiremt Rainfall } & \multicolumn{3}{|c|}{ Belg Rainfall } & \multicolumn{3}{|c|}{ Bega Rainfall } & \multicolumn{3}{|c|}{ Annual Rainfall } \\
\hline & Mean & CV & CT & Mean & CV & CT & Mean & $\mathrm{CV}$ & CT & Mean & CV & PCI \\
\hline Alemketema & 834 & 23 & 80 & 164 & 65 & 16 & 43 & 103 & 4 & 1040 & 20 & 21 \\
\hline Alyuamba & 714 & 29 & 54 & 397 & 69 & 31 & 177 & 97 & 15 & 1362 & 30 & 13 \\
\hline Debrebirhan & 721 & 18 & 79 & 156 & 37 & 17 & 39 & 84 & 4 & 908 & 13 & 23 \\
\hline Effeson & 702 & 36 & 66 & 265 & 53 & 24 & 112 & 81 & 11 & 1060 & 22 & 17 \\
\hline Enewari & 748 & 31 & 83 & 154 & 64 & 16 & 31 & 143 & 2 & 878 & 29 & 22 \\
\hline Genager & 1071 & 20 & 61 & 484 & 56 & 27 & 209 & 72 & 12 & 1765 & 19 & 14 \\
\hline Gisherabe & 673 & 27 & 81 & 135 & 46 & 15 & 37 & 76 & 3 & 812 & 21 & 25 \\
\hline Gudoberet & 950 & 39 & 81 & 175 & 54 & 14 & 84 & 91 & 6 & 1150 & 40 & 21 \\
\hline Gundomeskel & 776 & 24 & 80 & 166 & 45 & 16 & 43 & 71 & 3 & 952 & 20 & 20 \\
\hline Majete & 739 & 23 & 63 & 301 & 39 & 26 & 136 & 80 & 12 & 1174 & 16 & 16 \\
\hline Mehalmeda & 633 & 42 & 76 & 166 & 47 & 19 & 40 & 84 & 5 & 824 & 36 & 21 \\
\hline Meragna & 742 & 24 & 82 & 150 & 55 & 16 & 32 & 82 & 3 & 900 & 21 & 22 \\
\hline Molale & 693 & 25 & 75 & 161 & 50 & 17 & 70 & 104 & 8 & 925 & 20 & 21 \\
\hline Rema & 747 & 19 & 83 & 121 & 67 & 13 & 31 & 102 & 3 & 904 & 17 & 24 \\
\hline Shewarobit & 687 & 30 & 64 & 239 & 52 & 23 & 132 & 90 & 13 & 1083 & 26 & 16 \\
\hline Sholagebeya & 762 & 31 & 77 & 178 & 54 & 18 & 45 & 101 & 5 & 996 & 29 & 20 \\
\hline Yigem & 790 & 39 & 76 & 223 & 50 & 20 & 65 & 82 & 4 & 1005 & 32 & 20 \\
\hline Zemero & 654 & 23 & 82 & 135 & 50 & 16 & 25 & 98 & 2 & 790 & 18 & 24 \\
\hline Areal mean & 757 & 28 & 75 & 209 & 53 & 19 & 75 & 91 & 6 & 1029 & 24 & 20 \\
\hline
\end{tabular}

Table 2 shows that the study area received annual rainfall ranging from $790 \mathrm{~mm}$ to $1765 \mathrm{~mm}$ with a mean of $1029 \mathrm{~mm}$ and CV of 24\%; CV varied from 13-40\%. At the seasonal level, Kiremt rainfall varied from $633-1071 \mathrm{~mm}$ with mean of $757 \mathrm{~mm}$. For Kiremt, the mean $\mathrm{CV}$ was $28 \%$; CV revealed high $(\mathrm{CV}=42 \%$ ) and less $(\mathrm{CV}=18 \%)$ variability. The mean total rainfall amount for Belg and Bega were 209 and 75 millimeters; they varied from 121$484 \mathrm{~mm}$ and $25-209 \mathrm{~mm}$, respectively. Bega rainfall was extremely variable (CV > 70\%) for all stations. As compared to Kiremt season, the Belg rainfall was more variable. For example, CV for Belg was 53\%; it ranged from 37-69\%. This agrees with the study by Woldeamlak \& Conway (2007) [35]. Based on Hare (1983) classification, North Shewa has been vulnerable to drought during Belg season (CV > 30\%). Generally, the seasonal variability was higher than the annual variability. This agrees with the findings of previous studies conducted in Ethiopia [36]. 
CT for Kiremt was very high (CT = 75\%); it ranged from 54$83 \%$. This is supported by Bewket \& Conway [35] and Ayalew et al. [5]. Belg rainfall also contributed a considerable amount for the annual total rainfall (CT = 19\%); it ranged from 13-31 $\%$. For Bega rainfall the mean areal CT was 6\%; it ranged from $2-15 \%$. The analysis of PCI showed that in all stations the rainfall pattern was not uniformly distributed. Generally low or no rainfall was received from October to February while intensive rainfall was received between July and September. The maximum and minimum Kiremt rainfall amount was $942.9 \mathrm{~mm}$ (occurred in 2007) and 361mm (occurred in 1987). Refer Figure 2 for the corresponding values for Belg and Bega seasons.

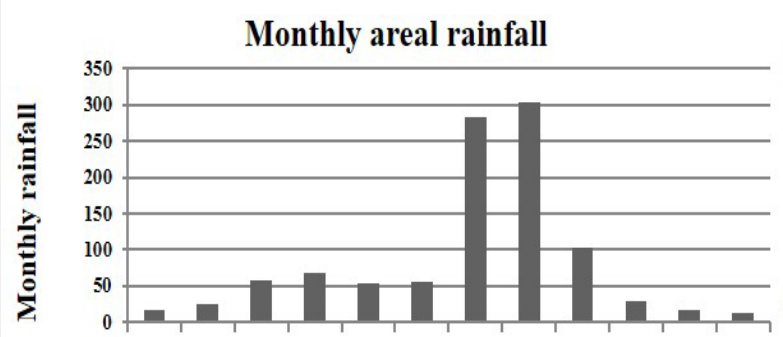

Jan Feb Mar Apr May Jun Jul Aug Sep Oct Nov Dec

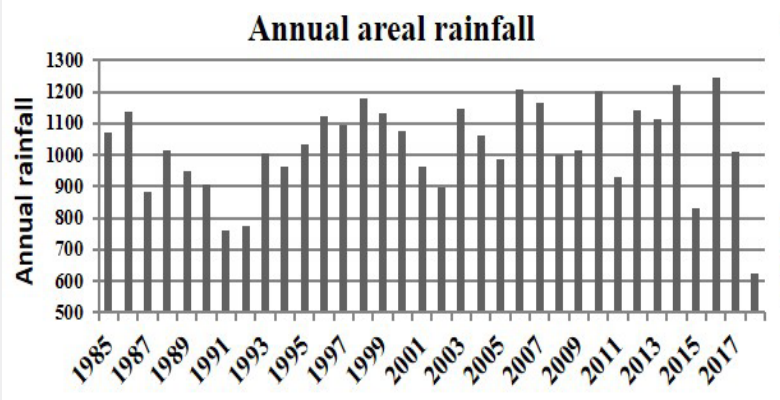

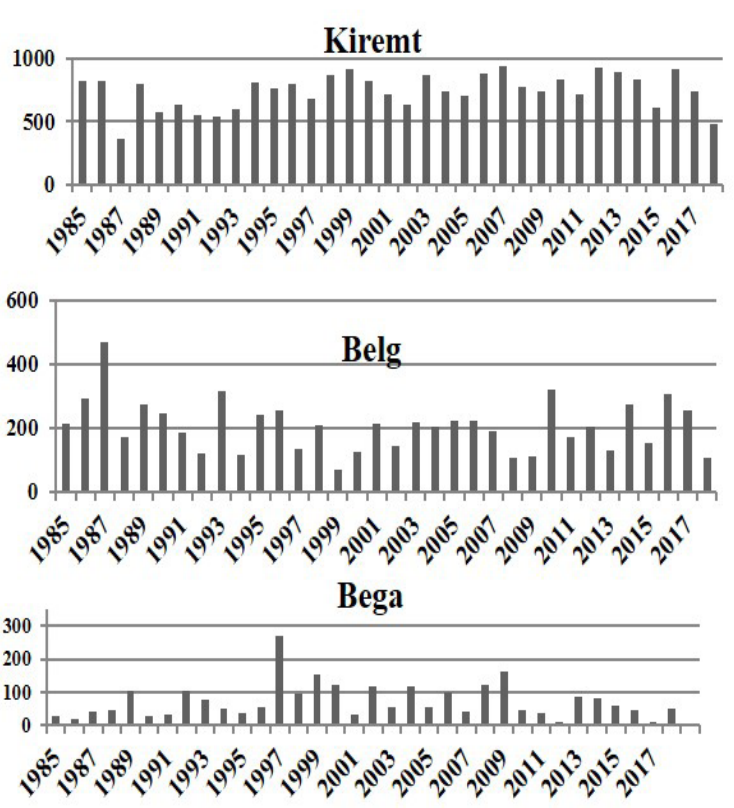

Figure 2: Monthly, Annual, and Seasonal rainfall climatology (in mm).

Figure 3 shows the spatial distribution of rainfall for the annual and seasonal time scales. Generally, the rainfall distribution showed a general decrease in annual mean rainfall from south to north. See Figure 3 for the corresponding seasonal rainfall distribution.

\section{Annual and seasonal rainfall anomalies}

Figure 4 shows the annual and seasonal rainfall anomalies. The result of SRA showed a 50\% dry tendency and 50\% wet tendency over the study area on annual basis. For Kiremt season $47 \%$ showed weak to strong negative departure from the long term mean rainfall and 53\% recorded above the long-term average rainfall. Likewise, SRA during Belg and Bega season showed 50\% and 59\% dry tendency dominancy, respectively. According to the drought assessment method by Agnew and Chappel (1999), seven dry years: two extremes (1987 and 2018), two severe (1991 and 1992), and three moderate $(1989,1993$ and 2015) dry years were identified. In contrast, 2007 and 2012 had experienced severe wet years; while that of 1998, 2003 and 2013 showed moderate wet years during Kiremt season.
Figure 5 shows the average of 3-month SPI for a period of three years (2016-2018) and ten years (2009-2018) for Belg season. According to the 3-month SPI analysis, in both periods North Shewa had experienced from extremely dry (SPI $\leq-2)$ to extremely wet (SPI $\geq 2$ ) conditions. Comparatively, the three years (2016-2018) were a bit drier than the ten years (2009-2018). The areal average 3-month SPI for 1985-2018, 2009-2018, and 20162018 was $0.14,0.13$, and 0.09 , respectively which is in agreement with the trend of SRA for Belg season (see Figure 4).

\section{The Onset, Cessation, and Length of Growing Period of Kiremt} season

The lowest, highest, and mean LGP was 55, 138, and 78 days, respectively (see Table 3). In a similar study conducted in Tigray region (northern Ethiopia) for the period 1980-2009, Hadgu et al. [37] found the average LGP to vary from 66 to 85 days. The coefficient of variation (CV) of LGP ranged from 14-87\%. Higher $\mathrm{CV}(>13 \%)$ of LGP gives less confidence in crop selection based on the maturity period. 

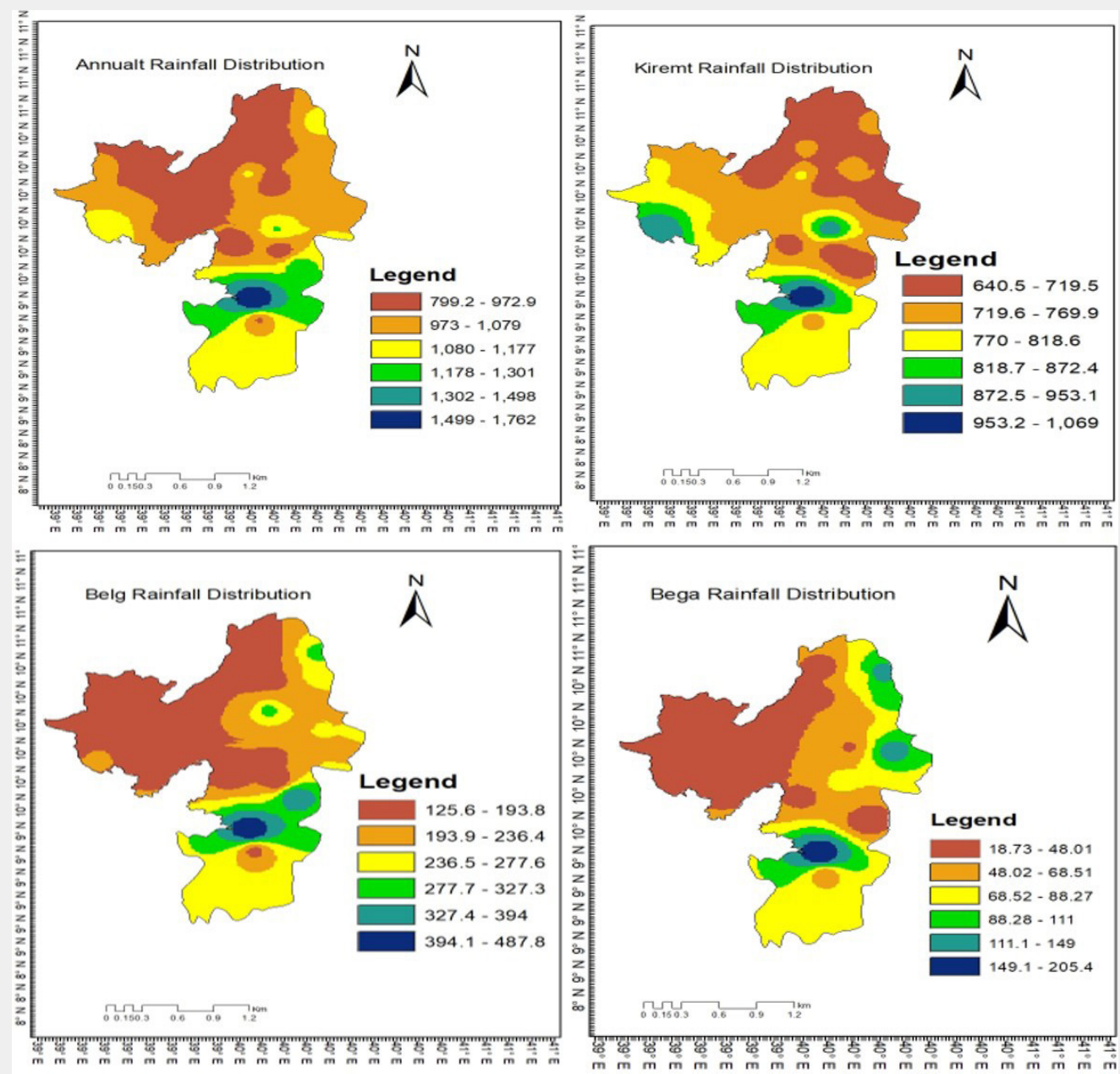

Figure 3: Spatial distribution of annual and seasonal rainfall climatology (in $\mathrm{mm}$ ).
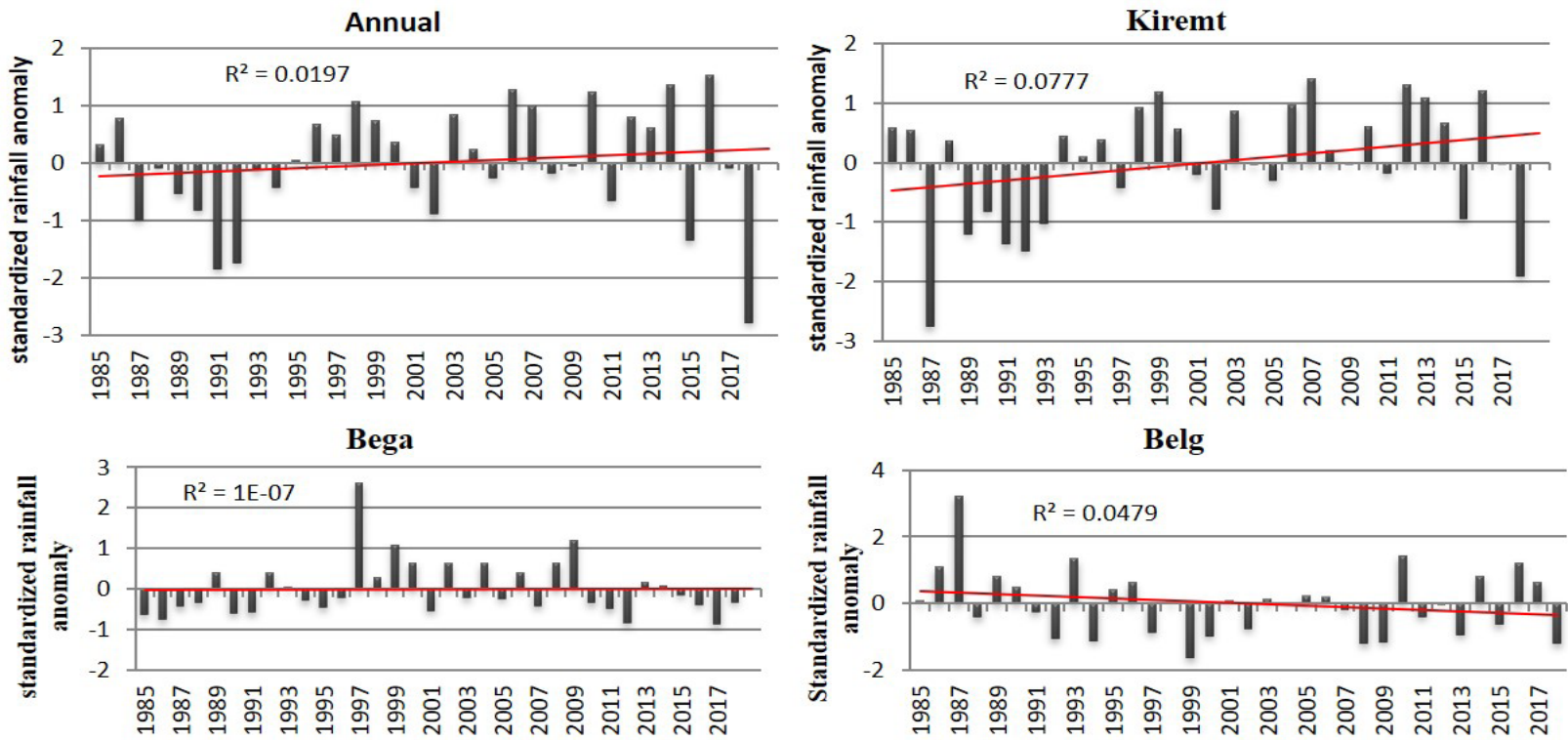

Figure 4: Annual and seasonal areal rainfall anomaly (in $\mathrm{mm}$ ) in North Shewa. 


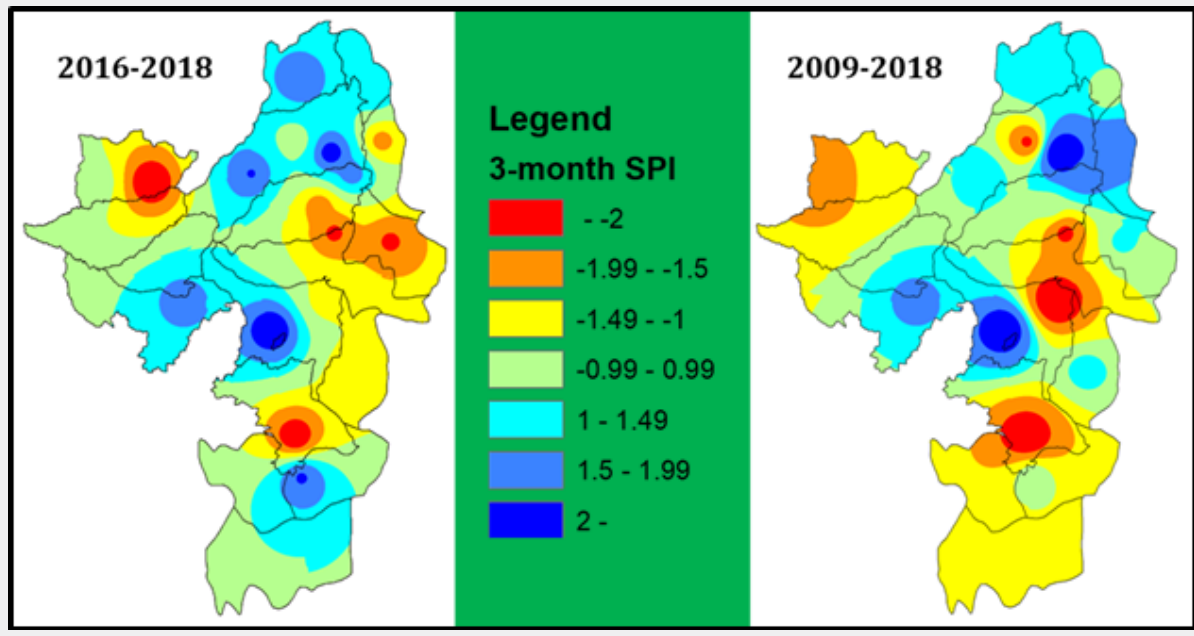

Figure 5: Areal average 3-month SPI for 2016-2018 and 2009-2018 over North Shewa.

Table 3: The mean and coefficient of variance of onset, cessation, length of the growing period and number of rainy days of Kiremt season (19852018).

\begin{tabular}{|c|c|c|c|c|c|c|c|c|}
\hline \multirow{2}{*}{ Stations } & \multicolumn{2}{|c|}{ Onset } & \multicolumn{2}{|c|}{ Cessation } & \multicolumn{2}{|c|}{ Length of Growing Period } & \multicolumn{2}{|c|}{ Number of Rainy Days } \\
\hline & Mean & CV (\%) & Mean & CV (\%) & Mean & CV (\%) & Mean & CV (\%) \\
\hline Alemketema & 175 & 6.3 & 277 & 3.3 & 65 & 78.6 & 67 & 12.9 \\
\hline Alyuamba & 182 & 7.4 & 282 & 4.1 & 82 & 51.6 & 40 & 24.5 \\
\hline Debrebirhan & 182 & 15.3 & 277 & 5.2 & 80 & 60.9 & 63 & 22.6 \\
\hline Effeson & 189 & 10.3 & 278 & 5.3 & 57 & 87.4 & 52 & 17.3 \\
\hline Enewari & 169 & 18.5 & 276 & 2.8 & 70 & 80.1 & 68 & 21.9 \\
\hline Ginager & 171 & 7 & 295 & 5.7 & 79 & 78.8 & 62 & 17.4 \\
\hline Gisherabel & 186 & 6.1 & 271 & 3 & 56 & 76.5 & 61 & 15.8 \\
\hline Gudoberet & 173 & 19.1 & 283 & 6.8 & 70 & 86.3 & 66 & 27.5 \\
\hline Gundomeskel & 171 & 6.4 & 283 & 5.1 & 87 & 58.9 & 59 & 27.3 \\
\hline Majete & 184 & 9.1 & 286 & 3.8 & 102 & 19.6 & 58 & 12.7 \\
\hline Mehalmeda & 159 & 23.4 & 297 & 9.7 & 138 & 29.7 & 57 & 31.3 \\
\hline Meragna & 179 & 6.1 & 278 & 3.5 & 63 & 78.8 & 68 & 16.1 \\
\hline Molale & 185 & 6.7 & 274 & 4.4 & 55 & 82.9 & 61 & 18.7 \\
\hline Rema & 173 & 7.3 & 290 & 7.1 & 74 & 82.1 & 66 & 17.9 \\
\hline Shewarobit & 178 & 9 & 287 & 6.9 & 111 & 44.8 & 57 & 18.2 \\
\hline Sholagebeya & 177 & 7.4 & 280 & 3 & 104 & 14 & 65 & 15.5 \\
\hline Yigem & 183 & 8.7 & 278 & 5.3 & 62 & 81 & 64 & 21.5 \\
\hline Zemero & 184 & 6.6 & 272 & 2.7 & 57 & 76 & 64 & 15 \\
\hline Areal mean & 178 & 10 & 281 & 4.9 & 78 & 64.9 & 61 & 19.7 \\
\hline
\end{tabular}

In a study conducted in northern Ethiopia, Hadigu et al. [37] found the start (onset) date of Kiremt growing areas to be between the $1^{\text {st }}$ and $3^{\text {rd }}$ week of July. In contrast, in this study, the mean onset date was varied from 159 DOY (June -6) to 189 DOY (July6). The areal mean onset date was 178 DOY (June -25) in the study area. The observed variability of Kiremt onset was varied from 6-19\%. The onset date of Kiremt growing areas had experienced dependable patterns across Gisherabel; while at Gudoberet the patterns were not easily understood and consequently decisions of crop plantation and related activities should be taken with great care. Similarly, the mean cessation date ranged from 271 DOY (Sep-26) to 297 DOY (Oct-23) areas; the areal mean cessation date was 281 DOY (Oct-7). At all the probability levels considered, the end of Kiremt season was more extended at Mehalmeda compared to other areas. 
Figure 6 presents the spatial distributions of onset, cessation, LGP, and number of rainy days. The first two graphs show the mean spatial onset (the start) and the cessation (the end) of Kiremt season where the numbers in the legend are the DOYs. For example, DOY of $159.1(\sim 159)$ means the $6^{\text {th }}$ of June and DOY of $188.8(\sim 189)$ means the $7^{\text {th }}$ of July, and so forth. Accordingly, the western part and some pocket areas in the northern, central and southern parts of the study area had early onset of Kiremt rainfall while late onset was observed in the northern and at some pocket areas in the central parts of the study area. Similarly, the cessation date of Kiremt season was early $\left(27^{\text {th }}\right.$ of September) in a few northern and western pocket areas; it was late ( $23^{\text {rd }}$ of October) in a few southern, northern and eastern pocket areas.
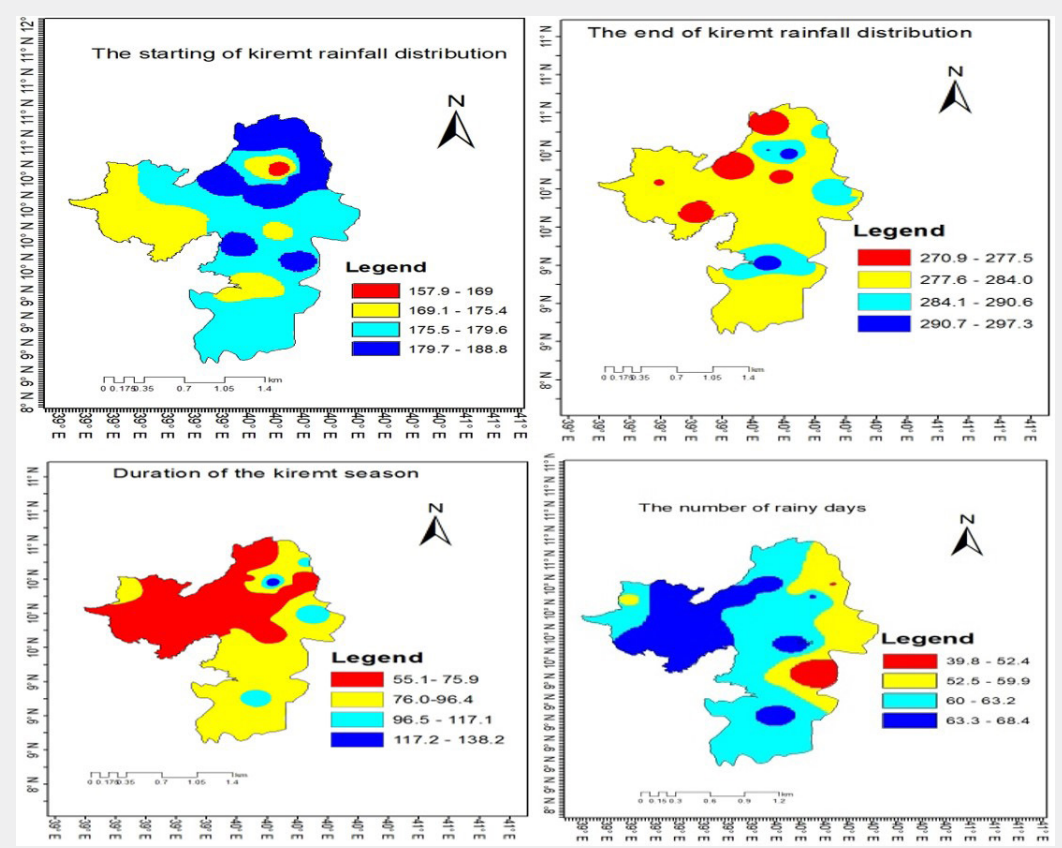

Figure 6: Onset, cessation, duration, and number of rainy days distribution of Kiremt.

\section{Number of rainy days and probability of dry spell length}

For Kiremt season, the number of rainy days varied from 40 68 days with an areal mean of 61 days (see Table 3). The interannual variability of the number of rainy days ranged from 13$31 \%$ with an areal mean of 19.7 days.

The probability of dry spell occurrence for Belg (DOY = 32152 ) and Kiremt (DOY $=153-274)$ seasons for ten selected stations is shown in Figure 7; dry spell lengths of 5,7,10, and 15 days were considered. Observations of the rainfall data illustrated that the probability of dry spells occurring within the growing seasons varied from month to month. During Belg season, the probability of the occurrence of dry spells for 5, 7, 10, and 15 dry spell days was above $40 \%$ in all stations. In the main rainy season (Kiremt), the probability of 7, 10, and 15 days dry spell occurrence in July and August was zero; whereas for 5 days dry spell it was more than $30 \%$ at all stations.

Generally, the shorter dry spell events have a higher probability of occurrence, compared to the longer ones. Also, Belg season had a higher probability of dry spells than Kiremt season and is liable to meteorological drought.

The challenges of the risk of the dry spell were more at Molale, Gundomeskel and Enewari areas. This implies that, in these areas, the risk of planting long cycle crops before June is above $65 \%$.

\section{Annual and seasonal rainfall trends}

The Mann-Kendall trend test showed a decreasing trend of annual rainfall at Alemketema, Alyuamba, Rema and Shewarobit areas (see Table 4). Only at Alyuamba station, the detected trends were significant at $5 \%$ significant level. This agrees with the results of Seleshi [9]; Cheung \& McSweeney C [10]; Viste et al. [12]; NMA [38]; they reported statistically non-significant declining tendency in annual rainfall across Ethiopia between 1960 and 2006. On the contrary, the annual and Kiremt rainfall in North Shewa showed a statistically non-significant increasing trend (increased by a factor of 37 and $39 \mathrm{~mm}$ per decade, respectively). This agrees with the result of the study by Bewket \& Conway [35]; they showed that the annual and Kiremt rainfall at Dessie and Lalibela for the period 1975-2003 had a significant increasing trend. Belg and Bega rainfall had shown a non-significant decreasing trend. 

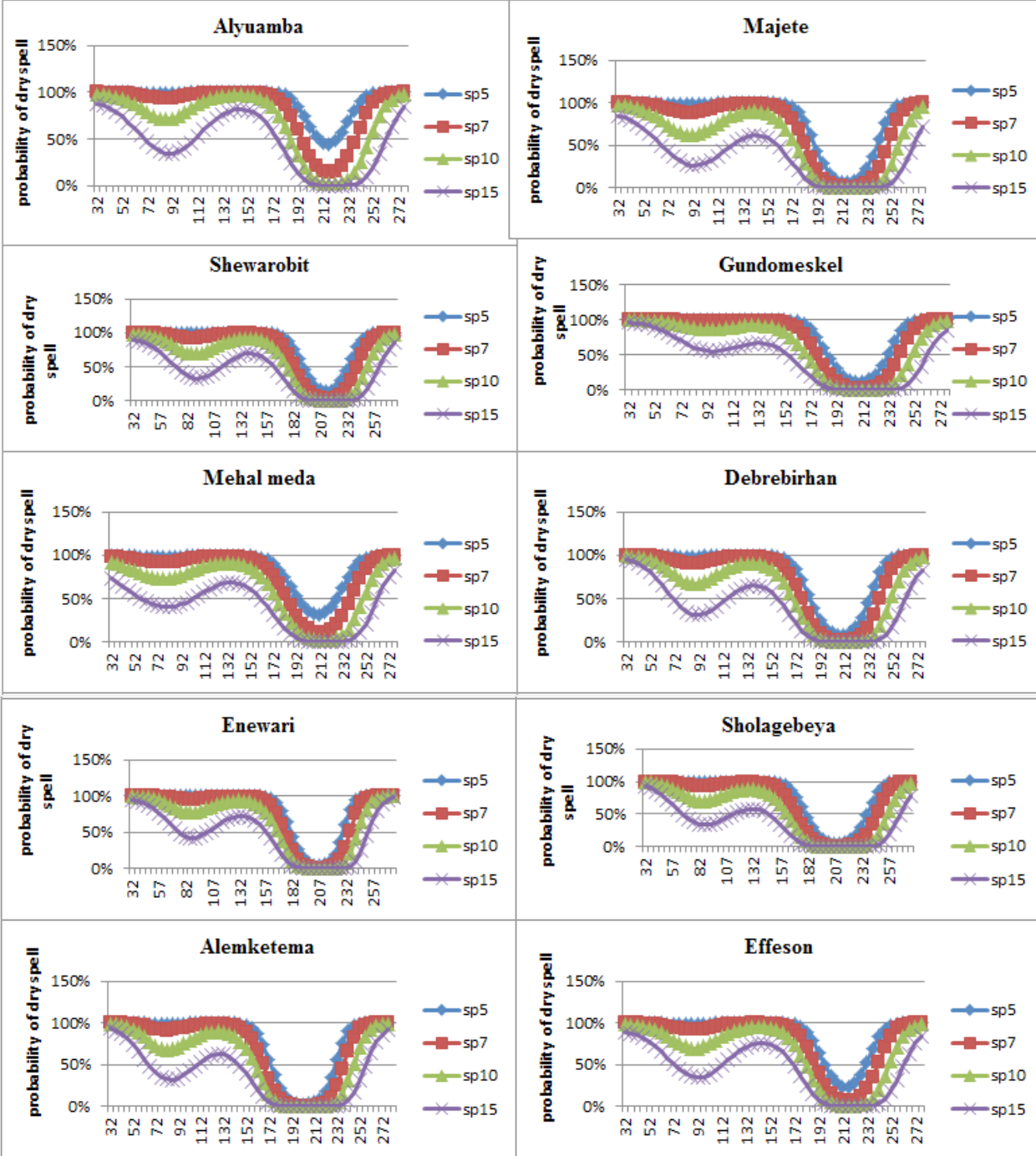

Figure 7: The probability of dry spell occurrence for 5, 7, 10, 15 days in Belg and Kiremt seasons.

Table 4: Trends of annual and seasonal rainfall in North Shewa (1985-2018).

\begin{tabular}{|c|c|c|c|c|c|c|c|c|c|c|c|c|}
\hline \multirow{2}{*}{ Stations } & \multicolumn{3}{|c|}{ Annual Rainfall } & \multicolumn{3}{|c|}{ Kiremt Rainfall } & \multicolumn{3}{|c|}{ Belg Rainfall } & \multicolumn{3}{|c|}{ Bega Rainfall } \\
\hline & ZMK & $\mathbf{Q}$ & $\mathbf{P}$ & ZMK & $\mathbf{Q}$ & $\mathbf{p}$ & ZMK & $\mathbf{Q}$ & $\mathbf{P}$ & ZMK & $\mathbf{Q}$ & p \\
\hline Alemketema & -0.12 & -3.9 & 0.33 & -0.04 & -0.93 & 0.75 & -0.15 & -1.5 & 0.22 & -0.08 & 0.28 & 0.49 \\
\hline Alyuamba & -0.45 & -25.4 & 0 & -0.29 & -9.5 & 0.01 & -0.36 & -12.8 & 0 & -0.01 & -1.44 & 0.43 \\
\hline Debrebirhan & 0.21 & 3.9 & 0.08 & 0.18 & 3.2 & 0.14 & -0.02 & -0.13 & 0.86 & 0 & -0.02 & 1 \\
\hline Effeson & 0.12 & 5.3 & 0.33 & 0.37 & 9.9 & 0 & -0.25 & -5.9 & 0.39 & -0.09 & -1.33 & 0.43 \\
\hline Enewari & 0.37 & 12.7 & 0 & 0.31 & 9.3 & 0.01 & 0.22 & 2.85 & 0.07 & 0.28 & 0.8 & 0.02 \\
\hline Ginager & 0.01 & 0.42 & 0.94 & 0.15 & 5.6 & 0.21 & 0 & -0.38 & 0.99 & -0.06 & -1.1 & 0.61 \\
\hline Gisherabel & 0.45 & 11.9 & 0 & 0.44 & 12.1 & 0 & -0.14 & -1.4 & 0.23 & 0.19 & 0.68 & 0.12 \\
\hline Gundoberet & 0.39 & 21.6 & 0 & 0.43 & 18 & 0 & 0.23 & 3.7 & 0.06 & 0.14 & 1.28 & 0.25 \\
\hline Gundomeskel & 0.32 & 10.2 & 0.01 & 0.31 & 9.2 & 0.01 & -0.06 & -0.55 & 0.64 & 0.08 & 0.34 & 0.53 \\
\hline
\end{tabular}




\section{International Journal of Environmental Sciences \& Natural Resources}

\begin{tabular}{|c|c|c|c|c|c|c|c|c|c|c|c|c|}
\hline Majete & 0.09 & 2.9 & 0.44 & 0.23 & 6.1 & 0.07 & -0.14 & -2.5 & 0.26 & 0.07 & 1.04 & 0.59 \\
\hline Mehalmeda & 0.31 & 6.8 & 0.01 & 0.31 & 7.3 & 0.01 & -0.05 & -0.53 & 0.7 & 0.23 & 0.82 & 0.06 \\
\hline Meragna & 0.29 & 9.9 & 0.02 & 0.23 & 6.3 & 0.07 & 0.19 & 2.6 & 0.13 & 0.31 & 0.92 & 0.01 \\
\hline Molale & 0.14 & 4.5 & 0.27 & 0.23 & 6 & 0.06 & -0.22 & -2.1 & 0.08 & 0.19 & 1.01 & 0.11 \\
\hline Rema & -0.08 & -2.2 & 0.53 & -0.08 & -1.7 & 0.51 & -0.11 & -0.89 & 0.38 & 0.05 & 0.13 & 0.67 \\
\hline Shewarobit & -0.06 & -3.1 & 0.66 & -0.12 & -3.8 & 0.32 & -0.03 & -0.37 & 0.84 & 0.04 & 0.59 & 0.73 \\
\hline Sholagebeya & 0.01 & 0.3 & 0.93 & 0.11 & 2.8 & 0.36 & -0.21 & -2.45 & 0.08 & 0 & 0 & 1 \\
\hline Yigem & 0.47 & 23.1 & 0 & 0.44 & 21 & 0 & 0.21 & 3.8 & 0.08 & 0.14 & 1.14 & 0.25 \\
\hline Zemero & 0.33 & 9 & 0.01 & 0.37 & 7.7 & 0 & 0.11 & 1.3 & 0.38 & 0.18 & 0.4 & 0.14 \\
\hline Areal mean & $\mathbf{0 . 1 7}$ & $\mathbf{3 . 7}$ & $\mathbf{0 . 1 6}$ & $\mathbf{0 . 2 1}$ & $\mathbf{3 . 9}$ & $\mathbf{0 . 0 8}$ & $\mathbf{- 0 . 1 2}$ & $\mathbf{- 1 . 6}$ & $\mathbf{0 . 3 4}$ & $\mathbf{- 0 . 0 1}$ & $\mathbf{- 0 . 0 4}$ & $\mathbf{0 . 9 5}$ \\
\hline
\end{tabular}

Trends of onset and cessation days of rainfall for Kiremt season

The Mann-Kendall trend test on onset of Kiremt rainfall showed a decreasing trend in all stations except Alyuamba and Meragna stations (see Table 5). The observed trends were statistically significant only at Gisherabel, Yigem and Gundomeskel stations while in the remaining stations the trends were not significant. The cessation date of Kiremt rainfall showed an increasing trend in fourteen stations; in the four stations (Gudoberet, Mehalmeda, Rema and Zemero), the trend was statistically significant.

Table 5: Trends of onset and cessation days, length of growing period

and number of rainy days during Kiremt season at eighteen stations for the period 1985-2018.

\begin{tabular}{|c|c|c|c|c|c|c|c|c|c|c|c|c|}
\hline \multirow[b]{2}{*}{ Stations } & \multicolumn{3}{|c|}{ Onset } & \multicolumn{3}{|c|}{ Cessation } & \multicolumn{3}{|c|}{ Length of Growing Period } & \multicolumn{3}{|c|}{ Number of Rainy Days } \\
\hline & ZMK & $\mathbf{Q}$ & $\mathbf{p}$ & ZMK & $\mathbf{Q}$ & $\mathbf{P}$ & ZMK & $\mathbf{Q}$ & $\mathbf{P}$ & ZMK & $\mathbf{Q}$ & $\mathbf{p}$ \\
\hline Alemketema & -0.13 & -0.22 & 0.28 & -0.01 & 0 & 1 & 0.13 & 0.28 & 0.28 & 0.17 & 0.2 & 0.17 \\
\hline Alyuamba & 0.08 & 0.11 & 0.43 & -0.14 & -0.22 & 0.25 & -0.12 & -0.33 & 0.32 & 0.19 & 0.25 & 0.12 \\
\hline Debrebirhan & -0.03 & -0.02 & 0.83 & 0.01 & 0 & 0.95 & -0.01 & -0.1 & 0.95 & 0.29 & 0.33 & 0.01 \\
\hline Effeson & -0.08 & -0.17 & 0.51 & -0.04 & -0.1 & 0.75 & 0.01 & 0 & 0.96 & 0.02 & 0 & 0.87 \\
\hline Enewari & -0.09 & -0.17 & 0.41 & 0.04 & 0.04 & 0.77 & 0.06 & 0.21 & 0.6 & 0.01 & 0 & 0.96 \\
\hline Ginager & -0.08 & -0.12 & 0.53 & -0.21 & -0.5 & 0.08 & -0.13 & -0.23 & 0.29 & -0.14 & -0.23 & 0.25 \\
\hline Gisherabel & -0.3 & -0.33 & 0.01 & 0.23 & 0.22 & 0.06 & 0.29 & 0.56 & 0 & 0.42 & 0.46 & 0 \\
\hline Gundoberet & -0.19 & -0.4 & 0.12 & 0.26 & 0.61 & 0.03 & 0.29 & 1.18 & 0.01 & 0.29 & 0.73 & 0.02 \\
\hline Gundomeskel & -0.29 & -0.48 & 0.02 & 0.22 & 0.29 & 0.08 & 0.29 & 0.73 & 0.01 & 0.39 & 1.04 & 0 \\
\hline Majete & -0.1 & -0.2 & 0.41 & -0.08 & -0.12 & 0.53 & 0.03 & 0.06 & 0.83 & 0.17 & 0.14 & 0.17 \\
\hline Mehalmeda & -0.18 & -0.25 & 0.09 & 0.38 & 1.58 & 0 & 0.43 & 2.3 & 0 & 0.42 & 0.83 & 0 \\
\hline Meragna & 0 & 1 & 0 & 0.13 & 0.2 & 0.29 & 0.06 & 0.1 & 0.63 & 0.19 & 0.23 & 0.12 \\
\hline Molale & -0.05 & -0.1 & 0.71 & 0.05 & 0.1 & 0.67 & 0.07 & 0.2 & 0.56 & 0.19 & 0.33 & 0.11 \\
\hline Rema & -0.23 & -0.44 & 0.06 & 0.24 & 0.71 & 0.04 & 0.28 & 1.4 & 0.02 & -0.18 & -0.38 & 0.14 \\
\hline Shewarobit & -0.06 & -0.15 & 0.64 & 0.16 & 0.48 & 0.21 & 0.1 & 0.45 & 0.41 & -0.15 & -0.25 & 0.24 \\
\hline Sholagebeya & -0.04 & -0.04 & 0.7 & 0.06 & 0.1 & 0.63 & -0.04 & -0.1 & 0.73 & 0.22 & 0.27 & 0.08 \\
\hline Yigem & -0.28 & -0.67 & 0.02 & 0.01 & 0 & 0.93 & 0.39 & 1.5 & 0 & 0.42 & 0.73 & 0 \\
\hline Zemero & -0.19 & -0.33 & 0.11 & 0.27 & 0.18 & 0.03 & 0.25 & 0.4 & 0.04 & 0.25 & 0.28 & 0.04 \\
\hline Areal mean & -0.71 & -3.6 & $\mathbf{0}$ & 0.22 & 0.2 & 0.07 & 0.34 & 0.5 & 0.01 & 0.32 & 0.31 & 0.01 \\
\hline
\end{tabular}

Generally, the Mann-Kendal trend test showed that the onset date had been decreasing non-significantly by 36 days per decade while that of cessation date had been increasing non-significantly by 2 days per decade in the study area.

The length of the growing period (LGP) showed an increasing trend in fourteen stations; in seven stations the trend was statistically significant. In line with this Kelemu S [39] reported decreasing trends of the length of the growing period at Debretabor and Wereta stations in South Gonder zone for the period 1985-2014. Generally, in North Shewa the test showed statistically significant increasing trends of rainfall by 5 days per decade over the last 34 years. 
On the other hand, the number of rainy days had shown increasing trends in all areas except at Ginager, Rema, and Shewarobit areas. Generally, the number of rainy days had shown statistically significant increasing trends in the study area; it had increased by 3.1 days per decade [40].

\section{Conclusion}

In this study, detailed analysis of the temporal and spatial characteristics of rainfall using rainfall data obtained from the National Meteorological Agency of Ethiopia for 34 years (19852018) is presented. The data used is a combination of gauge and gridded rainfall data which is believed to be more reliable than using lonely satellite rainfall data. Rainfall is the major climatic parameter that needs to be analyzed for its statistical characteristics in order to conduct successful rain-fed agriculture over central Ethiopia. Variation of rainfall in both time and space has a significant effect in the performance of agricultural productivity, particularly over central Ethiopia where agriculture heavily relies on seasonal rainfall.

North Shewa is characterized by bimodal rainfall pattern where much of the rainfall concentrated in the main rainy season called Kiremt (June-September) and a small amount of rainfall received in the second rainy season called Belg (February-May). Bega (October-January) is a relatively dry season. The mean annual rainfall amount was $1029 \mathrm{~mm}$ while Kiremt, Belg, and Bega received 757, 209, and 75 millimeters respectively. The mean onset and cessation dates were June $25^{\text {th }}$ and October $7^{\text {th }}$, respectively while the mean duration of the Kiremt season was 78 days.

The result showed that there was considerable temporal and spatial variation of rainfall over North Shewa. The coefficient of variation of the annual and Kiremt rainfall revealed moderate inter-annual and seasonal variability. However, much larger variation was observed during Belg and Bega season. On the other hand, the result of coefficient of variation showed low variability in the onset and cessation dates; whereas, the length of growing period was highly variable. Spatially, a general decrease of mean annual rainfall from south to north was observed. Moreover, the rainfall was characterized by a sporadic fluctuation of wet and dry years in a periodic pattern.

Trends of rainfall at annual and seasonal time scales for the study period were analyzed using the Mann-Kendall test and Sen's slope estimator. The tests for annual and Kiremt rainfall resulted in non-significant increasing trends; increased by 37 and $39 \mathrm{~mm}$ per decade, respectively. The result of the test showed non-significant decreasing trends by 16 and $0.4 \mathrm{~mm}$ per decade, during Belg and Bega seasons, respectively. Also, the onset dates decreased nonsignificantly by 36 days per decade; whereas, cessation dates showed a non-significant increasing trend of 2 days per decade. Likewise, the length of growing period also showed a statistically significant increasing trend of 5 days per decade. On the other hand, the number of rainy days increased significantly by 3.1 days per decade.

During Belg season, the probability of the occurrence of dry spells for $5,7,10$, and 15 dry spell days was above $40 \%$ in all stations. The information on the length of dry spells can be used as input in decision making concerning crop selection, supplementary irrigation water demand scheduling, and in other agricultural activities.

This study has offered useful information for a better understanding of the temporal trends and spatial distribution of rainfall in the study area, which is of great importance for water and forest resources management particularly in securing sustainable agricultural production. Moreover, this study can be used as an input for a more comprehensive study that may include the impact of the temporal rainfall trends and the spatial rainfall variabilities on water, agriculture, and forests as well as on the driving forces that caused the variabilities and trends.

\section{Acknowledgment}

The authors thank the National Meteorological Agency of Ethiopia (NMA) for providing all the data used for this study.

\section{Data Availability Statement}

All data used during the study were provided by a third party. Direct requests for these materials may be made to the provider as indicated in the Acknowledgements. All code used during the study are available from the authors by request.

\section{References}

1. Weldegerima TM, Zeleke TT, Birhanu BS, Zaitchik BF, Fetene ZA (2018) Analysis of Rainfall Trends and Its Relationship with SST Signals in the Lake Tana Basin, Ethiopia. Advances in Meteorology 2018(5869010): 10 .

2. Degefu MA, Rowell DP, Bewket W (2016) Teleconnections between Ethiopian rainfall variability and global SSTs: observations and methods for model evaluation. Meteorol Atmos Phys (2017) 129: 173186.

3. (2014) United States Environmental Protection Agency.

4. Warwade P, Tiwari S, Ranjan S, Chandniha SK, Adamowski J (2018) Spatio-temporal variation of rainfall over Bihar State, India. Journal of Water and Land Development 36(1): 183-197.

5. Ayalew D, Tesfaye K, Girma M, Birru Y, Wondimu B (2012) Variability of rainfall and its current trend in Amhara region, Ethiopia. African Journal of Agricultural Research 7(10): 1475-1486.

6. Wagesho N, Goel NK, Jain MK (2013) Temporal and spatial variability of annual and seasonal rainfall over Ethiopia. Hydrological Sciences Journal 58(2): 354-373.

7. Gamachu D (1988) Some patterns of altitudinal variation of climatic elements in the mountainous regions of Ethiopia. MRD 8(2/3): 131138.

8. Segele ZT, Lamb PJ (2005) Characterization and variability of Kiremt rainy season over Ethiopia. Meteorol Atmos Phys 89: 153-180. 
9. Seleshi Y, Zanke U (2004) Recent changes in rainfall and rainy days in Ethiopia. Int J Climatol 24: 973-983.

10. Cheung WH, Senay G, Singh A (2008) Trends and spatial distribution of annual and seasonal rainfall in Ethiopia. Int J Climatol 28(13): 17231734 .

11. Jury MR, Funk C (2012) Climatic trends over Ethiopia: regional signals and drivers. Int J Climatol 33(8): 1924-1935.

12. Viste E, Korecha D, Sorteberg, A (2013) Recent drought and precipitation tendencies in Ethiopia. Theoretical and Applied Climatology 112: 535-551.

13. Korecha D, Barnston A (2007) Predictability of June-September rainfall in Ethiopia. Mon Weather Rev 135: 628-650.

14. Segele ZT, Lamb PJ, Leslie LM (2009a) Large-scale atmospheric circulation and global sea surface temperature associations with Horn of Africa June-September rainfall. Int J Climatol 29: 1075-1100.

15. Segele Z, Lamb PJ, Leslie LM (2009b) Seasonal-to-inter-annual variability of Ethiopia/Horn of Africa monsoon. Part I: associations of Wavelet-Filtered large-scale atmospheric circulation and global sea surface temperature. J Climate 22: 3396-3421.

16. Bekele F, Mosisa N, Terefe D (2017) Analysis of current rainfall variability and trends over Bale-Zone, South Eastern highland of Ethiopia. Climate Change 3(12): 889-902

17. Bekele-Biratu E, Thiaw WM, Korecha D (2018) Sub-seasonal variability ofthe Belg rains in Ethiopia. Int J Climatol 38(7): 2940-2953.

18. Bui, Hieu Thi, Eshidaira H, Shaowei N (2019) Evaluation of the use of global satellite-gauge and satelliteonly precipitation products in streamflow simulations. Applied Water Science 9(53).

19. Sun Q, Miao C, Duan Q Ashouri H, Sorooshian S, et al. (2018) A review of global precipitation data sets: Data sources, estimation, and intercomparisons.Reviews of Geophysics 56(1): 79-107.

20. NSHSB (2007) North Shewa Highland Sheep and Barley, livelihood profile Amahra, Ethiopia.

21. Shefine BG (2018) Analysis of Meteorological Drought Using SPI and Large-Scale Climate Variability (ENSO) - A Case Study in North Shewa Zone, Amhara Regional State, Ethiopia. Hydrol Current Res 9: 307.

22. Zenebe Mekonnen (2020) Precipitation and Temperature Projections for Medium-High Emission Scenario by General Circulation Models for Ethiopia. Int J Environ Sci Nat Res 23(4): 556119.

23. Tukey J (1977) Exploratory data analysis. Reading. MA: AddisonWesley.

24. Allen R (1998b) Crop evapotranspiration: Guidelines for computing crop water requirements, Irrigation and Drainage Paper No. 56. FAO, Rome, Italy.

25. Vergni L, Todisco F (2011) Spatio-temporal variability of precipitation, temperature and agricultural drought indices in central Italy. Agricultural and Forest Meteorology 151(3): 301-313.

26. Tung YK (1983) Point Rainfall Estimation for a Mountainous Region. J Hydraulic Engine 109(10): 1386-1393.

27. Watson DF, Philip GM (1985) A Refinement of Inverse Distance Weighted Interpolation. Geo-Processing 2(4): 315-327.

28. Gocic M, Shamshirband S, Razak Z, Petkovic D, Ch S, et al. (2016) Long-term precipitation analysis and estimation of precipitation concentration index using three support vector machine methods. Advances in Meteorology 2016(7912357): 11.

29. WMO-No. 1090 (2012) Standard Precipitation Index User Guide.

30. Nicholson S (1985) Sub-Saharan Rainfall 1981-84. J Climate Appl Meteorolo 24: 1388-1391.

31. Partal T (2006) Trend analysis in Turkish precipitation data. Hydrological Process 20(9): 2011-2026.

32. Yenigun K, Gumus V, Bulut H (2008) Trends in streamflow of the Euphrates basin, Turkey. Proclamation Institute of Civil Engineering Water Management 161(4): 189-198.

33. Sen P (1968) Estimates of regression coefficients based on Kendall's tau. Journal of the American Statistical Association 63(324): 13791389.

34. Hamed KH, Rao AR (1998) A modified Mann-Kendall trend test for autocorrelated data. Journal of Hydrology 204(1-4): 182-196.

35. Bewket W, Conway D (2007) A note on the temporal and spatial variability of rainfall in the drought-prone Amhara region of Ethiopia. International Journal of Climatology 27 (11): 1467-1477.

36. Seleshi Y, Camberlin P (2006) Recent changes in dry spell and extreme rainfall events in Ethiopia. Theoretical and Applied Climatology 83: 181-191.

37. Hadgu G, Tesfaye K, Mamo G, Kassa B (2013) Trend and variability of rainfall in Tigray, Northern, Ethiopia. Analysis of meteorological data and farmers' perception. Academically Journal Environmental Science 1(8): 159-171.

38. National Meteorological Agency (NMA) (2007) Climate change national adaptation program of action of Ethiopia. Technical report, United Nations Development Program (UNDP). Addis Ababa, Ethiopia.

39. Kelemu S (2016) Analysis of climate variability and its interconnection with major crops production in the South Gondar Zone, Amhara National Regional State, Ethiopia. MSc thesis submitted to Post Graduate Program Directorate, Haramaya University, Ethiopia.

40. Conway D, Lisa E, Schipper F (2011) Adaptation to climate change in Africa: challenges and opportunities identified from Ethiopia. Global Environ Change 21(1): 227-237. 
DOI:10.19080/IJESNR.2020.24.556144

Your next submission with Juniper Publishers will reach you the below assets

- Quality Editorial service

- Swift Peer Review

- Reprints availability

- E-prints Service

- Manuscript Podcast for convenient understanding

- Global attainment for your research

- Manuscript accessibility in different formats ( Pdf, E-pub, Full Text, Audio)

- Unceasing customer service

Track the below URL for one-step submission https://juniperpublishers.com/online-submission.php 